\title{
Study on Activity of Cocoa Ethanolic Extract Against Shigella dysenteriae
}

Ariza Budi Tunjung-Sari ${ }^{\left.1^{*}\right)}$, Enny Suswati ${ }^{2)}$, Diana Chusna Mufida ${ }^{2)}$, Alfa Rianul Setiawan ${ }^{2)}$, Alvin Isnaini ${ }^{2}$, Alfa Rianul Setiawan ${ }^{2)}$, Mochamad Rizal ${ }^{2)}$, Teguh Wahyudi ${ }^{1)}$, and Misnawi ${ }^{1)}$

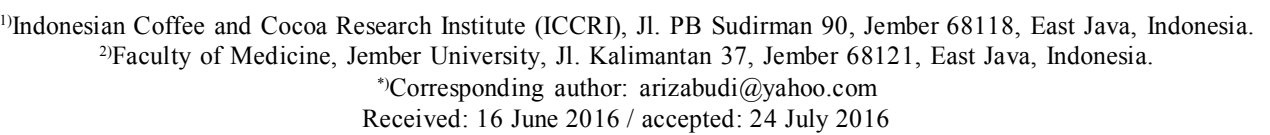

\begin{abstract}
Shigella dysenteriae is a gastrointestinal pathogen which shows resistance to antibiotics. A study has been conducted to investigate alternative antibacterial agents, due to the emerging resistance of $S$. dysenteriae to ciprofloxacin and other antibiotic classes. In this study, antibacterial properties of cocoa ethanolic extract (CEE) and its impact on growth and morphology of $S$. dysenteriae were evaluated. The effect of CEE on bacterial growth was assayed by using agar-well diffusion method and by observing morphological changes of bacterial cells through the use of scanning electron microscopy (SEM). Furthermore, CEE was also applied orally to mice infected with $S$. dysenteriae. The intestinal fluids was cultured in selective medium to evaluate growth of $S$. dysenteriae colonies. This study demonstrated that CEE at concentrations of $15.6 \mathrm{mg} / \mathrm{mL}$ inhibited $S$. dysenteriae growth, and at concentrations of $500 \mathrm{mg} / \mathrm{mL}$ and $1,000 \mathrm{mg} / \mathrm{mL}$ exhibited equal activity to $6.5 \mu \mathrm{g} / \mathrm{mL}$ of ciprofloxacin. SEM showed that $S$. dysenteriae cells had formed filaments, indicating that $\mathrm{CEE}$ caused cellular stress to $S$. dysenteriae. In in vivo assay, CEE showed suppression of $S$. dysenteriae colony in the mice intestine. This research suggests that CEE could potentially be used as antibacterial agent againsts $S$. dysenteriae.
\end{abstract}

Keywords: antibacterial, dysentery, cocoa, active compound, antibiotic

\section{INTRODUCTION}

The World Health Organization (WHO) reported that diarrhea killed 1.9 million people each year, including 760,000 children under five-year of age. In fact, the highest incidence of diarrhea was among infants 6-11 months of age, who typically suffered 4.5 diarrhea incidents per year (Walker et al., 2012). Among other diarrheal pathogens, Shigella dysenteriae produces the most severe disease and complications, because its Type- 1 species releases toxins.

Instead of vaccines, Shigella infection is treated by using antibiotics particularly from the class of $\beta$-lactams, quinolones or macrolides (Christopher et al., 2010). Among these, ciprofloxacin from quionolone class is the first line of treatment, while pivmecillinam, ceftriaxone and azithromycin are the most used second options (Christopher et al., 2010; WHO, 2005). However, Shiferaw et al. (2012) has reported resistance of Shigella towards ampicillin, streptomycin, trimethoprimsulfamethoxazole, sulfamethoxazole-sulfisoxazole, and tetracycline, and decreasing susceptibility against ciprofloxacin and nalidixic acid. Alternative antimicrobial agents for Shigella has been investigated from plant extract, for instance garlic and allicin (Andualem, 2013; Gull et al., 2012). Native medicinal plants, such as Channa striatus and Picralima nitida 
also demonstrated promising antimicrobial activity (Haniffa et al., 2013; Kouitcheu et al., 2013).

Cocoa bean (Theobroma cacao L.) was anciently utilized as a medicine, despite the current use for confectioneries. It is a valuable commodity for the Aztecs due to its nutrition, energetic, and aphrodisiac benefits. Cocoa beans were used to treat stomach and intestinal pains including dysenteriae as described in "Florentine Codex," a record of indigenous Aztec medical practices (Dillinger et al., 2000; Lippi, 2009). In recent times, health properties of cocoa beans have been extensively investigated, particularly for the prevention of cardiovascular diseases. We have found antibacterial properties against Escherichia coli, Staphylococcus aureus and Staphylococcus epidermidis, as well as immunomodulatory and anticancer properties (Sari et al., 2015; Sari et al., 2014; Sari et al., 2016). This study investigated the effects of cocoa ethanolic extract (CEE) on Shigella dysenteriae employing in vitro assay scanning electron microscopy (SEM) and in vivo testing in mice.

\section{MATERIALS AND METHODS}

Six kilograms of cocoa beans dried under the sun without prior fermentation, were ground into five-mesh particle size. The paste was pressed at $80-90^{\circ} \mathrm{C}$ to remove cocoa butter, and was soaked overnight in $\mathrm{n}$-hexane for thorough fat removal. The defatted mass was then filtered to remove liquid and the solid fraction was soaked in ethanol overnight. Finally, the ethanol extract was concentrated and spray dried to produce powder. Total polyphenol content (TPC) was measured using Folin-Ciocalteau method and was expressed as catechin equivalent and gallic acid equivalent.
Assessment of antibacterial activity was carried out by performing agar-well diffusion assay (Rojas et al., 2006). The CEE solution was prepared by diluting in sterile distilled water to create concentrations of 1,$000 ; 500 ; 250 ; 250 ; 125 ; 62.5 ; 31.3 ; 15.6$ and $7.8 \mathrm{mg} / \mathrm{mL}$. Positive control suspension was prepared from ciprofloxacin $6.5 \times 10^{-3} \mathrm{mg} /$ $\mathrm{mL}$, while negative control was prepared from sterile distilled water. Culture of $S$. dysenteriae $\left(1 \times 10^{8} \mathrm{CFU} / \mathrm{mL}\right)$ were streaked on plates containing Mueller Hinton agar. The agar was perforated to form well (diameter $10 \mathrm{~mm}, 4$ wells/plate) and the CEE solutions were poured into each well. Plates were incubated at $37^{\circ} \mathrm{C}$ for 24 hours, and development of clear area surrounding each well was observed. The inhibition zone was visible as a clear area surrounding each well. The inhibition zone diameter (IZD) was the diameter of the visible clear zone subtracted from the well diameter. The relative inhibition zone diameter (RIZD) of CEE was RIZD CEE $(\%)$ $=\left[\left(\mathrm{IZD}_{\mathrm{CEE}}-\mathrm{IZD}_{\text {Negative control }}\right) / \mathrm{IZD}_{\text {positive control }}\right]$ x 100\% (Rojas et al., 2006). The assay was done triplicate.

To observe morphological changes of the bacteria cells, $10 \mu \mathrm{L}$ of $S$. dysenteriae culture was added to vials containing CEE at concentrations of $7.8 \mathrm{mg} / \mathrm{mL}, 15.6 \mathrm{mg} / \mathrm{mL}$, and $31.2 \mathrm{mg} / \mathrm{mL}$, and was incubated at $35^{\circ} \mathrm{C}$ for 20 hours. The bacterial cells were fixated in glutaraldehyde $2 \%$ at $4^{\circ} \mathrm{C}$, and were immersed in osmic acid $1 \%$ at $4^{\circ} \mathrm{C}$ and were subsequently dehydrated with ethanol. Preservation of the cells were made by using absolute amyl acetate solution. The cells then were dried on glass prior to gold glazing and microspic observation process.

Male Swiss-Webster mice, aged 2-3 months with average weight of 25-30 g underwent acclimatization for one week prior to treatment. Mice were infected through intraperitoenal 
route with $1.5 \mathrm{~mL}$ suspension of $S$. dysenteriae culture $\left(10^{5} \mathrm{CFU} / \mathrm{mL}\right)$. Twenty four hours post infection, mice orally received CEE $(0.65 ; 1.3$; and $2.6 \mathrm{mg} / \mathrm{mL})$, ciprofloxacin $(1.3 \mathrm{mg} / \mathrm{mL})$, or sterile water $(1 \mathrm{~mL})$. Application was done twice a day for seven consecutive days. On the $8^{\text {th }}$ day, mice were sacrificed and the intestine wash was cultured in SS agar. After incubation for 20 days, colonies of $S$. dysenteriae shown in agar was counted. This trial has acquired ethical approval from committee from Faculty of Medicine, Jember University.

Experiment was done in triplicates and statistical analysis of the data used t-test, Kruskal-Wallis analysis, and Mann-Whitney test for post-hoc analysis.

\section{RESULTS AND DISCUSSION}

Secondary metabolites of plants have attracted studies on their antibacterial potency. Among these, polyphenol is considered as the most potent antibacterial agent, since its function in plant defense against predators. Polyphenol content in cocoa beans is higher than in fruits, such as pomegranates, cranberries, blueberries and acai berries (Crozier et al., 2011). Compared to other beverages, cocoa provides more phenolic content per serving than coffee, tea and wine. This studies showed that total phenolics (gallic acid equivalent) and flavonoids (epicatechin equivalents) in cocoa per serving were about two to three fold greater than that of black tea, green tea and red wine (Lee et al., 2003). Polyphenol accumulates in the nonfat solids of cocoa bean, thus the concentration is higher in chocolate products with less added ingredients. Chocolate, for instance, has less polyphenol content than cocoa powder and cocoa liquor ( $\mathrm{Gu}$ et al., 2006).
Cocoa polyphenol is composed largely of monomers, with a smaller number of trimers and tetramers (Misnawi et al., 2002). Extract of cocoa bean may contain tannin, (-)-epicatechin and (+)-catechin, and some of phenolic acids, flavonoids (quercetin, kaempferol, naringenin, myricetin, luteolin, and apigenin) and alkaloids (caffeine, theophylline and theobromine) (Elwers et al., 2009; Ortega et al., 2008; Sánchez Rabaneda et al., 2003). The alkaloids are distributed in various parts of cocoa (bean, pulp, and shell), where the amount is gradually decreasing during fermentation (Brunetto et al., 2007). Proportion between theobromine and caffeine content is different in each cocoa variety, whereas Criollo bean has lower theobromine/ caffeine concentration, while Forastero bean has high theobromine/caffeine concentration (Brunetto et al., 2007).

Fermentation of cocoa beans may reduce bitterness and astringency caused by polyphenol, hence its concentration. Misnawi et al. (2003) demonstrated that fermentation not only reduced polyphenol concentration but also altered the composition of anthocyanin, epicatechin and catechin. Alkalization step also degrades polyphenols in cocoa. By mixing cocoa powder with an alkaline solution (a practice known as "Dutch process"), one will produce a dark, yet mild tasting, cocoa powder. Degree of alkalization may be determined based on cocoa appearance, as light alkalization converts natural cocoa powder colors from light brown to red/brown and heavy alkalization results in dark red/black colors (Miller et al., 2008).

In this experiment, cocoa ethanolic extract (CEE) was produced from unfermented, unroasted, natural cocoa powder. The CEE contained TPC $140 \mathrm{mg} / \mathrm{g}(+)$-catechin equivalent and $397 \mathrm{mg} / \mathrm{g}$ (gallic acid equivalent), 
amounts that are almost 10-fold greater than in natural roasted cocoa powder (TPC $40.59-63.20 \mathrm{mg} / \mathrm{g}$ ) and 40-fold greater than in heavily alkalized powder (TPC $9.54 \mathrm{mg}$ / g) (Miller et al., 2008).

In in vitro assay, the inhibition zone diameter (IZD) of CEE was ranging from 0.4 to $11.1 \mathrm{~mm}$. After applying regression on IZD towards CEE concentration, a logarithmic response was observed $\left(R^{2}=0.9675\right)$. This experiment indicated that antibacterial activity was concentration-dependent, however the concentration higher than $500 \mathrm{mg} /$ $\mathrm{mL}$ may bring less significant effect. A comparable effect was shown from CEE at $500 \mathrm{mg}$ / $\mathrm{mL}, 100 \mathrm{mg} / \mathrm{mL}$ and ciprofloxacin $6.5 \times 10^{-3} \mathrm{mg} /$ $\mathrm{mL}(\mathrm{P}>0.05)$. On the other hand, there was no significant difference between the effect of CEE at $7.8 \mathrm{mg} / \mathrm{mL}$ and sterile water, indicating that in this concentration CEE was not effective as an antibacterial agent. RIZD, the ratio of IZD between the extract and positive control, is expressing the antimicrobial activity of CEE relative to ciprofloxacin (Rojas et al., 2006). A strong antibacterial activity was shown by CEE at concentrations between $500-1,000 \mathrm{mg} / \mathrm{mL}$, which featured a RIZD of $97-106 \%$ (Table 1).
The polyphenol in CEE may perform bacteriostatic and bactericidal activities through several actions, including disturbance of bacterial cell metabolism, inhibition of cell wall synthesis, disruption of cell membrane permeability, and interference with nucleic acid and gene expression (Cui et al., 2012; Denyer \& Maillard, 2002). Tannin works primarily on the bacterial outer membrane, since its protein-precipitation ability may interrupt membrane continuity (Liu et al., 2013). Research on green tea polyphenol, (-)-epigallocatechin-3-gallate (EGCG), demonstrated destructive activity toward E. coli, by inducing leakage and providing gateways to the cell interior (Cui et al., 2012). In addition to polyphenols, antibacterial activity of cocoa extract may be due to the presence of methylxanthines. Caffeine and derivate of theophylline were reported to decrease growth of gram-negative bacteria (Al-Janabi, 2011). Particularly, caffeine stimulates bacteria cell to undergo morphological changes and lysis (Dash \& Gummadi, 2008).

Susceptibility of gram-negative or grampositive bacteria is different, depending on characteristics of the cell wall. Gram-negative cells are equipped with a lipopolysaccharide

Table 1. Inhibition zone diameter (IZD) of CEE in various concentrations $(\mathrm{mg} / \mathrm{mL})$

\begin{tabular}{|c|c|c|c|}
\hline Treatment & Concentration $(\mathrm{mg} / \mathrm{mL})$ & $\mathrm{IZD}^{*}, \mathrm{~mm}$ & RIZD*, \% \\
\hline \multirow{8}{*}{ CEE } & 7.8 & $0.0 \pm 0.0^{\mathrm{a}}$ & 0 \\
\hline & 15.6 & $0.4 \pm 0.3^{\mathrm{c}}$ & 3 \\
\hline & 31.2 & $2.3 \pm 0.4^{\mathrm{d}}$ & 22 \\
\hline & 62.5 & $5.1 \pm 0.2^{\mathrm{e}}$ & 48 \\
\hline & 125 & $8.1 \pm 0.6^{\mathrm{f}}$ & 77 \\
\hline & 250 & $9.0 \pm 0.3^{\mathrm{g}}$ & 86 \\
\hline & 500 & $10.1 \pm 0.6^{\mathrm{b}}$ & 97 \\
\hline & 1,000 & $11.1 \pm 0.3^{\mathrm{b}}$ & 106 \\
\hline Ciprofloxacin & $6.5 \times 10^{-3}$ & $10.5 \pm 0.5^{\mathrm{b}}$ & 100 \\
\hline Sterile water & & $0 \pm 0^{\mathrm{a}}$ & 0 \\
\hline
\end{tabular}


outer membrane which determines virulence and resistance. Studies on tea $(+)$-catechin reported low bactericidal activity against gram-negative bacteria due to the negative charge of lipopolysaccharides (Kajiya et al., 2004). Nevertheless, the contact between proanthocyanidins and lipopolysaccharides may disrupt cellular homeostasis (Johnson et al., 2008).

SEM observation found that the $S$. dysenteriae cell in sterile water (negative control) was measured $2.04 \mu \mathrm{m}$ in length. After CEE exposure for 20 hours, the bacterial cells extended and formed filaments. Filamentation began at the lowest concentration of CEE, $7.8 \mathrm{mg} / \mathrm{mL}(4.89 \mu \mathrm{m})$, and continued at concentrations of $15.6 \mathrm{mg} / \mathrm{mL}$ $(6.39 \mu \mathrm{m})$ and $31.2 \mathrm{mg} / \mathrm{mL}(10.61 \mu \mathrm{m})$. The extended length of the cells indicates that the bacteria is receiving stress factors. Bacterial stress stimuli may include an unfavorable environment, nutritional imbalance, overpopulation, host immunity, and presence of toxins and antibiotics (Justice et al., 2008; Laureti et al., 2013; Poole, 2012). In response to stimuli, the stress response system (SOS response) is activated. This response system leads to cell shape modification, biofilm formation, mutation, and shifted virulence (Poole, 2012). When a DNA damage occurs, bacteria will delay mitosis to prevent transfer of defective DNA to the new cells. This condition leaves cells extend without cleaving, thus manifest in form of filaments (Justice et al., 2008).

In the in vivo assay, antibacterial potency was indicated from the ability of test sample to suppress the growth of the $S$. dysenteriae colony in the mice intestine. There were significant differences in number of $S$. dysenteriae colonies between sterile water and CEE treatments, except for CEE at the lowest dose $(0.56 \mathrm{mg} / \mathrm{mL})$. A similar effect was shown after application of CEE in equal dose with ciprofloxacin $(1.3 \mathrm{mg} / \mathrm{mL}, \mathrm{p}>0.05)$. CEE at the highest dose $(2.6 \mathrm{mg} / \mathrm{mL})$ had significantly reduced the colony number (Figure 1).

Interestingly, while in the in vitro assay the effective dose of CEE was $7 \times 10^{4}$-fold from ciprofloxacin (CEE $500 \mathrm{mg} / \mathrm{mL}$ vs. ciprofloxacin $6.5 \times 10^{-3} \mathrm{mg} / \mathrm{mL}$ ), in the in vivo assay the equal dose between $\mathrm{CEE}$ and ciprofloxacin had produced comparable effects. Doubling the dose of CEE from that

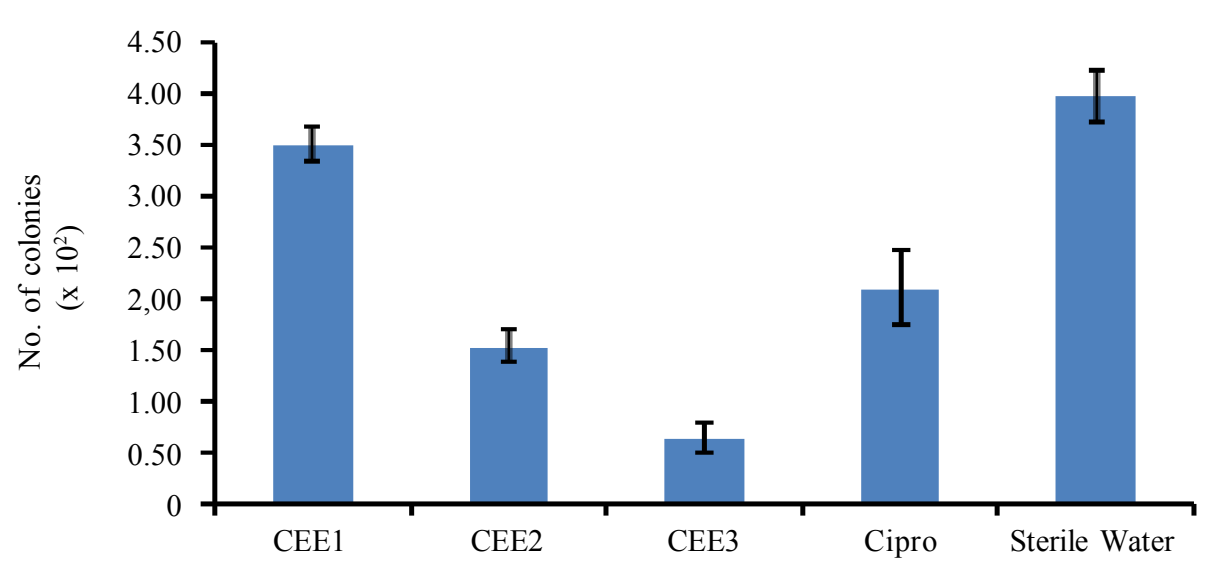

Figure 1. Number of $S$. dysenteriae colonies from mice intestine. CEE $1=0.56 \mathrm{mg} / \mathrm{mL}, \mathrm{CEE} 2=1.3 \mathrm{mg} / \mathrm{mL}$, CEE $3=2.6 \mathrm{mg} / \mathrm{mL}$, and Cipro = ciprofloxacin $1.3 \mathrm{mg} / \mathrm{mL}$ as positive control. Data are means of three replications (bars indicated standard deviation of means) 
of ciprofloxacin had significantly suppressed the colony growth. This indicates that CEE is not only attributed with antibacterial activity, but also with immuno-stimulation properties. Some studies revealed that cocoa polyphenols may induce changes composition and activity of immune cells as well as immune response. Ramiro-Puig et al. (2008) reported that a $10 \%$ cocoa diet had changed lymphosite composition in peyer's patches and mesenteric lymph nodes. In addition, VázquezAgell et al. (2011) demonstrated through a clinical study that cocoa consumption had acutely decreased the concentration of NF$\mathrm{kB}$, the signaling molecule mediating inflammation.

In an attempt of replacing conventional treatments, we could try to apply both CEE and an antibiotic, to utilize the benefits of both treatments. Similarly, studies have shown that a combination of (-)-epigallocatechin3-gallate (EGCG) and cefotaxime induced permanent damage in an $E$. coli cells, though those results have not been achieved by EGCG alone (Cui et al., 2012).

\section{CONCLUSIONS}

Antibacterial activity against $S$. dysenteriae was demonstrated by CEE, which had inhibited growth and triggered cellular stress. The effective dose in the in vivo assay was $1.3 \mathrm{mg} / \mathrm{mL}$ which equals to ciprofloxacin. This indicates that CEE may also stimulate immune system. This research suggests that CEE could potentially be used as a treatment of $S$. dysenteriae infection, though further investigation is necessary.

\section{REFFERENCES}

Al-Janabi, A.A.H.S. (2011). Potential activity of the purine compounds caffeine and aminophylline on bacteria. Journal of Global Infectious Diseases, 3, 133-137.
Andualem, B. (2013). Synergistic antimicrobial effect of Tenegn honey (Trigona iridipennis) and garlic against standard and clinical pathogenic bacterial isolates. International Journal of Microbiological Research, 4, 16-22.

Brunetto, M.a.d.R.; L. Gutiérrez; Y. Delgado; M. Gallignani; A. Zambrano; Á. Gómez; G. Ramos \& C. Romero (2007). Determination of theobromine, theophylline and caffeine in cocoa samples by a high-performance liquid chromatographic method with on-line sample cleanup in a switching-column system. Food Chemistry, 100, 459-467.

Christopher, P.; K.V. David; S.M. John \& V. Sankarapandian (2010). Antibiotic therapy for Shigella dysentery. Cochrane Database of Systematic Reviews, 8, 1-101.

Crozier, S.J.; A.G. Preston; J.W. Hurst; M.J. Payne; J. Mann,; L. Hainly \& D.L. Miller (2011). Cacao seeds are a "Super Fruit": A comparative analysis of various fruit powders and products. Chemistry Central Journal, 5, 1-6.

Cui, Y.; S.H. Kim; H. Kim; J. Yeom; K. Ko; W. Park \& S. Park (2012). AFM probing the mechanism of synergistic effects of the green tea polyphenol (-)-epigallocatechin3-gallate(EGCG) with cefotaxime against extended-spectrum beta-lactamase (ESBL)-producing Escherichia coli. Public Library of Science One, 7, 1-6.

Dash, S.S. \& S.N. Gummadi (2008). Inhibitory effect of caffeine on growth of various bacterial strains. Research Journal of Microbiology, 3, 457-465.

Denyer, S. \& J.Y. Maillard (2002). Cellular impermeability and uptake of biocides and antibiotics in Gram negative bacteria. Journal of Applied Microbiology, 92, 35-45.

Dillinger, T.L.; P. Barriga; S. Escárcega; M. Jimenez; D.S. Lowe \& L.E. Grivetti (2000). Food of the gods: cure for humanity? A cultural history of the medicinal and ritual use of chocolate. Journal of Nutrition, 130, 2057-2072. 
Elwers, S.; A. Zambrano; C. Rohsius \& R. Lieberei (2009). Differences between the content of phenolic compounds in Criollo, Forastero and Trinitario cocoa seed (Theobroma cacao L.). European Food Research and Technology, 229, 937-948.

Gu, L.; S.E. House; X. Wu; B. Ou \& R.L. Prior (2006). Procyanidin and catechin contents and antioxidant capacity of cocoa and chocolate products. Journal of Agricultural and Food Chemistry, 54, 4057-4061.

Gull, I.; M. Saeed; H. Shaukat; S.M. Aslam; Z.Q. Samra \& A.M. Athar (2012). Inhibitory effect of Allium sativum and Zingiber officinale extracts on clinically important drug resistant pathogenic bacteria. Annals of Clinical Microbiology and Antimicrobials, 11, $1-6$.

Haniffa, M.; P. Jeyasheela \& M.J. Milton (2013). In vitro antibacterial activity of tissue extracts from four channids against enteric pathogens. Journal of Agricultural Technology, 9, 1437-1445.

Johnson, B.J.; J.B. Delehanty; B. Lin \& F.S. Ligler (2008). Immobilized proanthocyanidins for the capture of bacterial lipopolysaccharides. Analytical Chemistry, 80, 2113-2117.

Justice, S.S.; D.A. Hunstad; L. Cegelski \& S.J. Hultgren (2008). Morphological plasticity as a bacterial survival strategy. Nature Reviews Microbiology, 6, 162-168.

Kajiya, K.; H. Hojo; M. Suzuki; F. Nanjo; S. Kumazawa \& T. Nakayama (2004). Relationship between antibacterial activity of $(+)$-catechin derivatives and their interaction with a model membrane. Journal of Agricultural and Food Chemistry, 52, 1514-1519.

Kouitcheu, L.B.; J.L. Tamesse \& J. Kouam (2013). The anti-shigellosis activity of the methanol extract of Picralima nitida on Shigella dysenteriae type I induced diarrhoea in rats. BMC Complementary and Alternative Medicine, 13, 1-11.
Laureti, L.; I. Matic \& A. Gutierrez (2013). Bacterial responses and genome instability induced by subinhibitory concentrations of antibiotics. Antibiotics, 2, 100-114.

Lee, K.W.; Y.J. Kim; H.J. Lee \& C.Y. Lee (2003). Cocoa has more phenolic phytochemicals and a higher antioxidant capacity than teas and red wine. Journal of Agricultural and Food Chemistry, 51, 7292-7295.

Lippi, D. (2009). Chocolate and medicine: Dangerous liaisons? Nutrition, 25, $1100-1103$.

Miller, K.B.; W.J. Hurst; M.J. Payne; D.A. Stuart; J. Apgar; D.S. Sweigart \& B. Ou (2008). Impact of alkalization on the antioxidant and flavanol content of commercial cocoa powders. Journal of Agricultural and Food Chemistry, 56, 8527-8533.

Misnawi; S. Jinap; B. Jamilah \& S. Nazamid (2003). Effects of incubation and polyphenol oxidase enrichment on colour, fermentation index, procyanidins and astringency of unfermented and partly fermented cocoa beans. International Journal of Food Science \& Technology, 38, 285-295.

Misnawi; J. Selamat; J. Bakar \& N. Saari (2002). Oxidation of polyphenols in unfermented and partly fermented cocoa beans by cocoa polyphenol oxidase and tyrosinase. Journal of the Science of Food and Agriculture, 82, 559-566.

Ortega, N.d.; M.-P. Romero; A. Macial’; J. Reguant; N. Anglel̀s; J.-R.n. Morelloì \& M.-J. Motilva (2008). Obtention and characterization of phenolic extracts from different cocoa sources. Journal of Agricultural and Food Chemistry, 56, 9621-9627.

Poole, K. (2012). Bacterial stress responses as determinants of antimicrobial resistance. Journal of Antimicrobial Chemotherapy, 67, 2069-2089.

Ramiro-Puig, E.; F.J. Pérez-Cano; S. RamosRomero; T.Pérez-Berezo; C. Castellote; J. Permanyer; À. Franch; M. Izquierdo- 
Pulido \& M. Castell (2008). Intestinal immune system of young rats influenced by cocoa-enriched diet. The Journal of Nutritional Biochemistry, 19, 555-565.

Rojas, J.J.; V.J. Ochoa; S.A. Ocampo \& J.F. Muñoz (2006). Screening for antimicrobial activity of ten medicinal plants used in colombian folkloric medicine: A possible alternative in the treatment of nonnosocomial infections. BMC Complementary and Alternative Medicine, 6 , $1-6$.

Sánchez ,R.F.; O. Jáuregui; I. Casals; C. Andrés Lacueva; M. Izquierdo Pulido \& R.M. Lamuela-Raventós (2003). Liquid chromatographic/electrospray ionization tandem mass spectrometric study of the phenolic composition of cocoa (Theobroma cacao). Journal of Mass Spectrometry, 38, 35-42.

Sari, A.B.T.; D.C. Mufida; N.N. Fatima; T.I. Hendrayati; T. Wahyudi \& Misnawi (2014). In vitro antibacterial activity of cocoa ethanolic extract against Escherichia coli. International Food Research Journal, 21, 935-940.

Sari, A.B.T.; Mahriani; G.A.P. Tiningrum; T. Wahyudi \& Misnawi (2015). Cocoa extract indicated has activity on selectively killing breast cancer cells. The Journal of Tropical Life Science, 5, 128-132.
Sari, A.B.T.; T. Wahyudi; D.C. Mufida; M. Tamarizki; D. Perwitahati; I.K. Syamsuddin \& Misnawi (2016). The use of cocoa ethanolic extract for treatment of Staphylococcal infection in rabbit skin model. Pelita Perkebunan, 32, 34-42.

Shiferaw, B.; S. Solghan; A. Palmer; K. Joyce; E.J. Barzilay; A. Krueger \& P. Cieslak (2012). Antimicrobial susceptibility patterns of shigella isolates in foodborne diseases active surveillance network (foodnet) sites, 2000-2010. Clinical Infectious Diseases, 54, 458-463.

Vázquez-Agell, M.; M. Urpi-Sarda; E. Sacanella; S. Camino-López; G. Chiva-Blanch; V. Llorente-Cortés; E. Tobias; E. Roura; C. Andres-Lacueva \& R.LamuelaRaventós (2011). Cocoa consumption reduces $\mathrm{NF}-\kappa \mathrm{B}$ activation in peripheral blood mononuclear cells in humans. Nutrition, Metabolism and Cardiovascular Diseases, 23, 257-263.

Walker, C.L.F.; J. Perin;M.J. Aryee; C. BoschiPinto \& R.E. Black (2012). Diarrhea incidence in low-and middle-income countries in 1990 and 2010: a systematic review. BMC Public Health, 12, 1-7.

WHO (2005). Guidelines for Control of Shigellosis, Including Epidemics Due to Shigella dysenteriae Type1. World Health Organization Press, Geneva, Switzerlands.

$* * 0 * *$ 